\title{
Joining the Fight against Poverty: Open Invitation from the International Poverty and Health Network to All Health Professionals ${ }^{1}$
}

\author{
Iona Heath* and Andy Haines ${ }^{\dagger}$
}

The International Poverty and Health Network (IPHN) was created in December 1997, following a series of conferences organized by the World Health Organization. The aim of the Network is to "integrate health into poverty eradication policies and strategies, promoting community partnership and intersectoral action, as a means to achieve effective and sustainable results." It was formed in response to the evidence of the persistent and growing burden of human suffering due to poverty and it invites others to join the endeavour.

Around 1.3 billion people live in absolute, grinding poverty on less than $\$ 1$ per day despite the overall substantial growth of the world economy which doubled over the 25 years prior to 1998 to reach $\$ 24$ trillion (1). Of the 4.4 billion people in developing countries nearly three fifths lack access to sanitation, a third have no access to clean water, about one fifth lack access to health care of any kind, and a fifth do not have sufficient dietary energy and protein.

Economic disparities both within and between countries have grown and in about 100 countries incomes are lower in real terms than they were a decade or more ago (2). By 1995 the richest fifth of the world's population had 82 times the income of the poorest fifth. The world's 225 richest people have the combined wealth equivalent to the annual income of the poorest 2.5 billion people in the world (47\% of the world's population) (1). At the same time the world is facing a

\footnotetext{
* Royal College of General Practitioners, London, SW7 1PU, UK

$\dagger$ Department of Primary Care and Population Sciences, Royal Free and University College Medical School, London, NW3 2PF, UK

1 Versions of this article are expected to be published in several medical journals in order to draw attention to this matter.
}

growing scarcity of essential renewable resources from deforestation, soil erosion, water depletion, declining fish stocks, lost biodiversity and challenges such as climate change which are likely to impact particularly on poor, vulnerable populations.

Despite the overall dramatic increases in life expectancy over the last century, health professionals should be concerned about growing inequalities in health and wealth (3). The precipitous decline in life expectancy in Eastern Europe, particularly in Russia, is a graphic example of how health may deteriorate as societies face sudden social and economic change accompanied by growing poverty. The gap in life expectancy between selected western European countries and Russia has widened from about 3 years for men in 1970 to around 15 years in 1995; the figures for women show a widening from 4 to 10 years over the same period (4). This health crisis is centred particularly on adult mortality from chronic diseases and external causes, principally violence.

Many African countries have total external debts that are more than $100 \%$ of their gross national product. Although there has been progress in canceling debt, only 22 of the 52 countries needing substantial or total debt reduction will actually see their annual payments reduced following the agreements made at the Cologne summit (5). Therefore much remains to be done, including monitoring how the World Bank and International Monetary Fund implement the debt reduction program and ensuring that the economic policy reforms they recommend are focussed on reducing poverty.

Even amongst generally prosperous, industrialized nations, in countries including Spain, Finland, Sweden, 
Denmark and the United States, there are many examples of growing socioeconomic inequalities in health over the last 20 years or so (4). In the United Kingdom, there has been a widening of the differential in all cause mortality between Social Class V (unskilled) and Social Class I (professional) from a 2 fold difference in 1970-72 to almost a 3 fold difference in 1991-3 (6). The difference in life expectancy between these two social classes is now 9.5 years for men and 6.4 years for women, the greatest ever recorded in British history (7).

A matter of particular concern is that the lives of so many children are blighted by poverty (8). Even in the United States, more than one in four children under the age of 12 have difficulties obtaining sufficient food.

Ill health and poverty are mutually reinforcing and can generate a vicious cycle of deterioration and suffering. Ill health contributes directly to reduced productivity and, in some cases, to loss of employment. When it affects the principal earner in poor families it frequently has severe implications for economically dependent children, and other family members. By definition, poor people have very few reserves and may be forced to sell what assets they have, including land and livestock, or to borrow at high interest rates, in order to deal with the immediate crisis precipitated by illness. Each option leaves them more vulnerable, less able to recover their former condition, and in greater danger of moving down the poverty spiral. In contrast, effective and accessible health services can protect the poor from spiraling into worsening economic problems with the onset of illness, and community based health care has the potential to make a major contribution to the building of social capital and to the strengthening of the community's own coping mechanisms.

In the 20th century development has all too often been equated with economic growth, but the link between economic prosperity and health, a key component of human development, is not automatic. A recent World Bank study suggested that gains in income were responsible for one fifth of the reduction in mortality between 1960 and 1990 (9). The researchers indicated that educational level amongst women and the generation and utilization of new knowledge were more important factors.

Poverty is a social construction with many dimensions including lack of basic education, inadequate housing, social exclusion, lack of employment, environmental degradation, and low income. Each of these diminishes opportunity, limits choices and undermines hope, and each poses a threat to health. Economic indicators focus primarily on income poverty, whereas health indicators provide a measure of the multidimensional nature of poverty. For this reason, health should be the pre-eminent measure of the success of development policies in the next century. It is health, rather than economic, indicators which will demonstrate the importance of implementing policies across a range of sectors to slow the rate of depletion of renewable resources and, through the securing of human rights (10), to capitalise on the potential of those who are currently unable to improve their quality of life.

Health professionals strive to understand the detail of their patients' experience of illness and distress. Sharing the frustration and anger of those whose health is undermined by poverty provides understanding and is part of the process of developing solidarity with disadvantaged individuals and communities. Once suffering is expressed, it becomes tangible and demands redress. This is one of the fundamental processes of medicine and healing; it applies no less to social injustice. If we simply hear the story of suffering but make no move to work alongside the sufferer for redress, we abandon our task.

The IPHN is a world-wide network of people and organizations from the fields of health, business, nongovernment organizations, and government, who seek to influence policy to protect and improve the health of the world's poor, with particular emphasis on the poorest in all countries. The Network urges that a balance must be struck between social development and growth in per capita income; between the human and income dimensions of poverty; and between redistributive and market reforms. In terms of health, the aspiration is to achieve a balance between biomedical and social approaches; between community-based health development and an appropriate response to the needs of individuals; between preventive, promotive and curative health care; and between physical and mental health, with particular focus on the needs of the poorest and most vulnerable.

Over the next few years IPHN supporters will strive to reduce the burden of ill health due to poverty in the following ways:

- Engaging in strategic discussions with international institutions such as the International Monetary Fund, the World Bank, the World Health Organization, and national governments to ensure that health is placed at the centre of development and that health impact assessments of all policies are undertaken.

- Promoting intersectoral action for health at the local, regional, and national levels by working with sectors such as education, business, agriculture and transport to develop and implement effective policies.

- Building the evidence base on effective interventions to reduce inequalities in health and how improved health can reduce poverty. 
- Facilitating exchange of knowledge between health professionals in North and South about effective ways of working.

- Ensuring that education programs for health professionals include appropriate information on the impact of socioeconomic inequalities on health and what health professionals can do to reduce such inequalities.

- Encouraging health professionals to work with local communities to improve the health of the poorest;

- Monitoring trends in health inequalities and using the data to influence policy.

We invite others to join us in this endeavour.

\section{REFERENCES}

1. United Nations Development Programme. Human Development Report 1998. New York: Oxford University Press; 1998.

2. United Nations Development Programme. Human Development
Report 1996-1997. New York: Oxford University Press; 1997.

3. McCally M, Haines A, Fein O, et al. Poverty and ill health: physicians can and should make a difference. Annals of Internal Medicine 129: 726-733; 1998.

4. Whitehead M, Diderichsen F. International evidence on social inequalities in health. In: Drever F and Whitehead M, eds. Health Inequalities. London: Office of National Statistics; 1996.

5. Jubilee 2000 Coalition. Unfinished business. The world's leaders and the millennium debt challenge. London: Jubilee 2000 Coalition; 1999.

6. Drever F, Bunting J. Patterns and trends in male mortality. In: Drever F and Whitehead M, eds. Health Inequalities. London: Office of National Statistics; 1996.

7. Yamey G. Study shows growing inequalities in health in Britain. British Medical Journal 319: 1453; 1999.

8. UNICEF. The State of the World's Children 1998. New York: Oxford University Press; 1998.

9. Wang J, Jamison D, Bos E, et al. Measuring country performance on health: selected indicators for 115 countries. Health, Nutrition and Population Series. Washington DC: The World Bank; 1999.

10. Bagnoud F-X, Mann JM. Health and human rights. British Medical Journal 312: 924-925; 1996.

Dr Iona Heath is a general practitioner and Chairman of the Intercollegiate Forum on Poverty and Health, London, UK. Professor Andy Haines is at the Department of Primary Care and Population Sciences, Royal Free and University College Medical School, London, UK.

The following people have agreed to be signatories on the open invitation from the International Poverty and Health Network to all health professionals:

Judith A. Oulton, Chief Executive Officer, The International Council of Nurses;

Zorayda Leopando, Regional Vice-President for Asia-Pacific, World Alliance of National Colleges and Academies of Family Medicine and Family Practice (WONCA), the Philippines;

Dan Kaseje, Secretary General, Africa Community Action Network for Health (AFRI-CAN);

Whitney W. Addington, President, The American College of Physicians, The American Society of Internal Medicine;

Olivier Giscard d'Estaing, Chairman, BUSCO, Business Council to the UN, France;

James K. Tumwine, Associate Professor, Department of Paediatrics and Child Health, Makerere University Medical School, Kampala, Uganda;

Meri Koivusalo, Globalism and Social Policy Programme, National Research and Development Centre for Welfare and Health, Finland; Gillian Biscoe, Executive Director, The Bellettes Bay Company Inc., Australia;

Pat Nickson, Director, Institut Pan Africain de Santé Communautaire, Democratic Republic of Congo, Cote d'Ivoire.

For more information about the IPHN, please contact one of the following addresses:

International Poverty and Health Network (IPHN),

Health Link Worldwide, Cityside,

40 Adler Street, London E1 1EE, UK.

Tel: 0207539 1570, Fax: 0207539 1580,

E-mail: (Roger Drew) drew.r@healthlink.org.uk.
International Poverty and Health Network (IPHN), Community Health Cell, Society for Community Health and Awareness, Research and Action,

No. 326, 5th Main, 1st Block, Koramangala, Bangalore 560034 , India.

E-mail: (Thelma Narayan) sochara@blr.vsnl.net.in. 